\title{
Exporting raises productivity in sub-Saharan African manufacturing firms
}

\author{
Johannes Van Biesebroeck* \\ Department of Economics, University of Toronto, 150 St. George Street, Toronto, ON, \\ Canada M5S $3 G 7$ \\ NBER, USA
}

Received 27 January 2003; received in revised form 12 April 2004; accepted 14 December 2004

\begin{abstract}
Proponents of trade liberalization argue that exporting helps firms to achieve higher productivity levels. This hypothesis is examined for a panel of manufacturing firms in nine African countries. The results indicate that exporters in these countries are more productive and, more importantly, exporters increase their productivity advantage after entry into the export market. While the first finding can be explained by selection-only the most productive firms engage in exporting-the latter cannot. The results are robust when unobserved productivity differences and self-selection into the export market are controlled for using different econometric methods. Scale economies are shown to be an important channel for the productivity advance. Credit constraints and contract enforcement problems prevent firms that only produce for the domestic market from fully exploiting scale economies.
\end{abstract}

(C) 2005 Elsevier B.V. All rights reserved.

Keywords: Productivity; Export; sub-Saharan Africa; Causation

JEL classification: $\mathrm{F} 14 ; \mathrm{O} 12 ; \mathrm{O} 33$

* Tel.: +1 416946 5795; fax: +1 4169786713.

E-mail address: johannes.vanbiesebroeck@utoronto.ca.

0022-1996/\$ - see front matter (C) 2005 Elsevier B.V. All rights reserved.

doi:10.1016/j.jinteco.2004.12.002 


\section{Trade and productivity}

Because they interact with clients and competitors abroad, exporting firms in developing countries are relatively well positioned to absorb foreign knowledge. Many studies have provided prime face evidence of this phenomenon by documenting that exporters are systematically more productive than domestically oriented producers in the same country and industry, see for example Bernard and Jensen (1995), Aw and Hwang (1995), Tybout and Westbrook (1995), and Isgut (2001). However, most studies that pay attention to causal linkages have concluded that correlation between exporting and productivity largely reflects the self-selection of efficient firms into foreign markets, see Clerides et al. (1998), Bernard and Jensen (1999), Aw et al. (2000), and Delgado et al. (2002). ${ }^{1}$ In this paper I use panel data on African firms to demonstrate that, while selfselection matters, feedback from exporting to productivity is important too. I further demonstrate that this unusual finding may reflect the special economic conditions that prevail in African economies, including small domestic markets and poorly functioning credit markets.

The African countries and firms I study are introduced in Section 2, where I show that the simple correlation between productivity and export status holds at all levels of aggregation. In Section 3, I confirm for Africa that exporters differ in important ways from non-exporters. They pay higher wages, operate at a larger scale, are more capital-intensive, and have higher productivity. I also show that the new exporters increase the productivity gap relative to non-exporters after they enter foreign markets.

Section 4 establishes that the basic message of the paper-new African exporters exhibit post foreign-market entry improvements-is robust to the choice of econometric methodology. It does so using three alternative methodologies, two of which have failed to demonstrate post-entry improvements on other, non-African data sets. The first methodology treats simultaneity between productivity and export status using a generalized method of moments (GMM) estimator. The second methodology deals with simultaneity using the maximum likelihood approach developed by Clerides et al. (1998), and the third methodology does so by adapting the Olley and Pakes (1996) estimator to a context in which export status is endogenously chosen. Each of the three approaches produces an estimate for the effect of exporting on productivity between $25 \%$ and $28 \%$.

Finally, Section 5 links the basic finding on productivity and exporting to economic conditions in Africa. Approximately half of the productivity premium attributed to exporters is associated with the higher scale of operation. Exploiting scale economies domestically is difficult because of the small size of local markets and a combination of contractual problems with lack of credit. To expand sales, firms award trade credit, but domestic clients frequently default on payments. Finally, the production technology in most African firms is lagging worldwide best practice considerably, providing ample scope for productivity improvements through imitation and adoption of foreign

\footnotetext{
${ }^{1}$ One exception is Kraay (1999) who finds evidence for learning-by-exporting for Chinese plants, but only for established exporters, not for new entrants to the export market.
} 
technology. Tests for a structural break in the sample support the conclusion that exporters produce with a different technology than non-exporters.

\section{African exporters: literature, countries, and firms}

\subsection{Literature}

Using a variety of econometric methods and data from several countries, Bernard and Jensen (1999), Isgut (2001), Clerides et al. (1998), and Delgado et al. (2002) conclude in favor of the self-selection and against the learning-by-exporting hypothesis. Only the most productive firms have a sufficient cost advantage to overcome transportation costs and compete internationally. Exporters are more productive than non-exporters, not because there are any benefits associated with export activities, but they are simply more productive from the outset. Only a few studies-Kraay (1999) for China and Bigsten et al. (2004) for sub-Saharan Africa-reach the opposite conclusion. Aw et al. (2000) find evidence supporting learning-by-exporting in Taiwan, but not in South Korea.

Given the remaining trade protection in Africa and the large dispersion of productivity, potential benefits of liberalization could be substantial. Few studies investigate the link between trade and productivity at the firm- or plant-level. Mengistae and Patillo (2004) document a positive relationship for firms in Kenya, Ghana, and Ethiopia. While they show that their findings are consistent with learning effects, they stop short of making a causal interpretation. For Cameroon, Ghana, Kenya, and Zimbabwe, Bigsten et al. (2004) find a positive coefficient on lagged export status in the production function, but only when they model firm heterogeneity with discrete support, as in Heckman and Singer (1984), or when they ignore heterogeneity. When they integrate out a random firm effect, following Clerides et al. (1998), they obtain insignificant results in each specification, which they interpret as an inability to tell causation apart from time-invariant heterogeneity. A robustness check with instrumental variable estimation also comes up with an insignificant exporting effect. More puzzling, they find no effect of lagged export status on the export participation decision and capital intensity is not correlated with export status in any specification. The small size of their data set is one concern; they estimate with only 289 firms. Another potential problem is the restriction that all industries in all countries operate with the same production technology.

\subsection{Countries}

I study firms from Burundi, Cameroon, Cote d'Ivoire, Ethiopia, Ghana, Kenya, Tanzania, Zambia, and Zimbabwe. All nine are low-income countries in sub-Saharan Africa with GDP per capita ranging from \$446 in Ethiopia (PPP in 1995) to \$2195 in Zimbabwe. Value added per employee in industry is substantially higher, even converted using exchange rates. The share of manufacturing in GDP is relatively small in each country, but it exceeds employment in the sector by a wide margin. Some estimate that manufacturing workers are 2 to 3 times more productive than the average worker in the economy. Summary statistics are in Table 1. 
Table 1

Summary statistics for the nine sub-Saharan countries (1995)

\begin{tabular}{|c|c|c|c|c|c|c|}
\hline & \multirow{2}{*}{$\begin{array}{l}\text { GDP per } \\
\text { capita (PPP) }\end{array}$} & \multirow{2}{*}{$\begin{array}{l}\text { VA per employee } \\
\text { (industry-USD) }^{\mathrm{a}}\end{array}$} & \multirow{2}{*}{$\begin{array}{l}\text { Manufacturing } \\
\text { share in GDP }\end{array}$} & \multicolumn{2}{|l|}{ Export share } & \multirow{2}{*}{$\begin{array}{l}\text { Coverage } \\
\text { of GDP }\end{array}$} \\
\hline & & & & In manufacturing & $\left(\mathrm{EX}_{\mathrm{m}} / \mathrm{EX}_{\mathrm{tot}}\right)^{\mathrm{c}}$ & \\
\hline Ethiopia & 446 & 1690 & 0.07 & $0.23^{\mathrm{d}}$ & $0.30^{\mathrm{e}}$ & 0.79 \\
\hline Tanzania & 485 & 983 & 0.07 & 0.21 & 0.16 & 0.31 \\
\hline Burundi & 759 & 2450 & 0.13 & 0.06 & 0.09 & 0.65 \\
\hline Zambia & 936 & 5507 & 0.10 & 0.20 & 0.08 & 0.12 \\
\hline Kenya & 1112 & 1704 & 0.09 & 0.32 & 0.16 & 0.17 \\
\hline Ghana & 1511 & 1089 & 0.06 & $0.20^{\mathrm{d}}$ & $0.30^{\mathrm{e}}$ & 0.14 \\
\hline Cote d'Ivoire & 1588 & 5915 & 0.16 & 0.60 & 0.36 & 0.52 \\
\hline Cameroon & 1755 & 7904 & 0.10 & 0.21 & 0.14 & 0.63 \\
\hline Zimbabwe & 2195 & 7042 & 0.19 & 0.45 & 0.37 & 0.26 \\
\hline
\end{tabular}

Source: World Bank (2000), African Development Indicators (computer file).

a Industry is manufacturing, mining, and utilities.

${ }^{\mathrm{b}}$ Total value added in the first interview year as a percentage of manufacturing GDP.

c Share of manufactured goods in total exports.

d Total value added in GDP.

e Total value added in 1997 .

Most exports are concentrated in a few products and are transcontinental. ${ }^{2}$ In all countries but Zimbabwe, a single agricultural or mineral product accounts for more than $50 \%$ of all exports. Over the last two decades, most countries have tried to expand their manufacturing exports; Zambia, Cameroon, and Zimbabwe have been most successful. The share of manufacturing output that is exported ranges from $6 \%$ in Burundi to $60 \%$ in Cote d'Ivoire, averaging 29\% across countries. Manufactured products as a share of total exports $\left(\mathrm{EX}_{\mathrm{m}} / \mathrm{EX}_{\mathrm{tot}}\right)$ averages $23 \%$ and generally exceeds the manufacturing share in GDP.

\subsection{Firms}

The sample of manufacturing firms is constructed from firm surveys, carried out between 1992 and 1996. In each country approximately 200 firms were interviewed in (at most) three consecutive years. The data collection was coordinated by the Regional Program on Enterprise Development at the World Bank. Firms were sampled from four broadly defined manufacturing sectors: food, textile, wood, and metal. The sampling was stratified by firm-size and location; for more information on the firms and the sampling scheme, see Van Biesebroeck (2005). Combined value added for the firms included in the sample accounts for almost $40 \%$ of manufacturing GDP in the nine countries combined, see the last column of Table $1 .^{3}$ Findings for these firms will reflect the experiences of an important part of the manufacturing sector in the respective countries.

Value added, my output measure, is total sales minus raw materials, intermediate inputs and energy. Labor input is the total number of employees and capital is the replacement value of the plant and equipment at the end of the year. GDP deflators from the World Bank (2000)

\footnotetext{
${ }^{2}$ Europe is an important trading partner for each country; Japan, the U.S. and the Middle East are important for some.

${ }^{3}$ Because large firms are more productive, the share of the workforce sampled is significantly smaller.
} 
Table 2

Summary statistics for the sample of manufacturing firms

\begin{tabular}{|c|c|c|c|c|c|c|c|c|}
\hline & \multirow[t]{2}{*}{ Years } & \multirow{2}{*}{$\begin{array}{l}\text { No. of } \\
\text { firms }\end{array}$} & \multirow{2}{*}{$\begin{array}{l}\text { No. of } \\
\text { observations }\end{array}$} & \multirow{2}{*}{$\begin{array}{l}\text { VA per } \\
\text { employee } \\
\text { (USD) }\end{array}$} & \multicolumn{2}{|c|}{$\underline{\text { Export participation }}$} & \multirow{2}{*}{$\begin{array}{l}\% \text { of sales } \\
\text { exported }\end{array}$} & \multirow{2}{*}{$\begin{array}{l}\% \\
\text { transcontinental }\end{array}$} \\
\hline & & & & & All firms & Large firms & & \\
\hline Ethiopia & 1 (1996) & 207 & 207 & 5493 & 0.02 & 0.15 & 0.40 & \\
\hline Tanzania & 3 (1992-1994) & 241 & 485 & 3057 & 0.09 & 0.60 & 0.24 & 0.43 \\
\hline Burundi & 1 (1993) & 105 & 105 & 6169 & 0.17 & 1.00 & 0.28 & \\
\hline Zambia & 3 (1992-1994) & 262 & 532 & 5689 & 0.09 & 0.48 & 0.19 & 0.22 \\
\hline Kenya & 3 (1992-1994) & 267 & 609 & 5993 & 0.22 & 0.68 & 0.31 & 0.24 \\
\hline Ghana & 3 (1991-1993) & 209 & 497 & 3845 & 0.11 & 0.30 & 0.31 & 0.54 \\
\hline $\begin{array}{l}\text { Cote } \\
\text { d'Ivoire }\end{array}$ & $2(1994-1995)$ & 188 & 303 & 10,930 & 0.44 & 0.87 & 0.54 & 0.53 \\
\hline Cameroon & 3 (1992-1994) & 234 & 557 & 9627 & 0.28 & 0.94 & 0.31 & 0.36 \\
\hline Zimbabwe & 3 (1992-1994) & 203 & 556 & 7618 & 0.49 & 0.86 & 0.20 & 0.27 \\
\hline
\end{tabular}

are used to make nominal values comparable across years. The labor productivity statistics in Table 2 are employment weighted averages of firm-level value added per employee. The oversampling of larger, more productive firms explains the uniformly higher productivity numbers, compared to the aggregate statistics for industry in Table 1.

Export market participation rates tend to rise with the share of manufacturing in GDP. Large firms, with more than 250 employees, are much more likely to engage in exporting. The majority of exporters sell less than $20 \%$ of total sales abroad, but large firms tend to export more. A sizeable share of exports, on average $41 \%$, leaves the continent.

An indication of the importance of manufacturing exports-and the subject of the remainder of the analysis-is the relation between productivity and export market activity. Across countries, the correlation coefficient between value added per worker and export share is 0.434 , even 0.523 for manufacturing. For our sample, the same correlation across country-industry pairs is 0.356 and for individual firms it is 0.256 (both are significant at a $1 \%$ level). Among exporters, the correlation between the value of exports and productivity is strongly positive. Of course, these simple correlations do not warrant any causality interpretation.

\section{Exporters are different}

Regressing firm characteristics on an export dummy (and controls), a number of studies have documented that exporters differ from non-exporters in important ways. Bernard and Jensen (1995) were the first to perform this exercise for the United States, Bernard and Wagner (1997) for Germany and Isgut (2001) for Colombia. The first row of Table 3 contains the corresponding results for the African firms. The African differences exceed those of the comparison countries, especially the more developed ones, so this sample is a promising place to find productivity effects of exporting. ${ }^{4}$ Most coefficients are significant at the $1 \%$ significance level and large in an economic sense.

\footnotetext{
${ }^{4}$ See Van Biesebroeck (2003) for a side by side comparison of the results for different countries.
} 
Table 3

OLS regressions of levels and growth rates with export status as explanatory variable

\begin{tabular}{|c|c|c|c|c|c|c|c|c|}
\hline Levels & $\ln W / L$ & $\ln S / L$ & $\ln \mathrm{VA} / L$ & $\ln K / L$ & $\ln I / L$ & $\ln S_{\mathrm{dom}}$ & $\ln L$ & $\mathrm{PF}^{\mathrm{a}}$ \\
\hline $\begin{array}{l}\text { Exporters } \\
\qquad\left(\mathrm{EX}_{t}=1\right)\end{array}$ & $\begin{array}{l}0.342 \\
(0.049)\end{array}$ & $\begin{array}{l}0.534 \\
(0.057)\end{array}$ & $\begin{array}{l}0.571 \\
(0.062)\end{array}$ & $\begin{array}{l}0.510 \\
(0.086)\end{array}$ & $\begin{array}{l}0.480 \\
(0.132)\end{array}$ & $\begin{array}{l}2.622 \\
(0.088)\end{array}$ & $\begin{array}{l}2.137 \\
(0.058)\end{array}$ & $\begin{array}{l}0.284 \\
(0.056)\end{array}$ \\
\hline $\begin{array}{l}\text { Exporters } \\
\qquad\left(\mathrm{EX}_{t}=1\right)\end{array}$ & $\begin{array}{l}0.403 \\
(0.053)\end{array}$ & $\begin{array}{l}0.649 \\
(0.061)\end{array}$ & $\begin{array}{l}0.683 \\
(0.067)\end{array}$ & $\begin{array}{l}0.593 \\
(0.093)\end{array}$ & $\begin{array}{l}0.581 \\
(0.144)\end{array}$ & $\begin{array}{l}2.921 \\
(0.091)\end{array}$ & $\begin{array}{l}2.380 \\
(0.059)\end{array}$ & $\begin{array}{l}0.664 \\
(0.085)\end{array}$ \\
\hline $\begin{array}{l}\text { Pre-export } \\
\qquad\left(\mathrm{EX}_{t}=0 \text { and }\right. \\
\left.\mathrm{EX}_{t+i}=1\right)\end{array}$ & $\begin{array}{l}0.304 \\
(0.096)\end{array}$ & $\begin{array}{l}0.574 \\
(0.109)\end{array}$ & $\begin{array}{l}0.611 \\
(0.120)\end{array}$ & $\begin{array}{l}0.305 \\
(0.166)\end{array}$ & $\begin{array}{l}0.257 \\
(0.268)\end{array}$ & $\begin{array}{l}1.918 \\
(0.189)\end{array}$ & $\begin{array}{l}1.278 \\
(0.125)\end{array}$ & $\begin{array}{l}0.552 \\
(0.104)\end{array}$ \\
\hline $\begin{array}{l}\text { Post-export } \\
\qquad\left(\mathrm{EX}_{t}=0 \text { and }\right. \\
\left.\mathrm{EX}_{t-i}=1\right)\end{array}$ & $\begin{array}{l}0.332 \\
(0.078)\end{array}$ & $\begin{array}{l}0.430 \\
(0.089)\end{array}$ & $\begin{array}{l}0.406 \\
(0.098)\end{array}$ & $\begin{array}{l}0.675 \\
(0.135)\end{array}$ & $\begin{array}{l}0.230 \\
(0.230)\end{array}$ & $\begin{array}{l}1.852 \\
(0.154)\end{array}$ & $\begin{array}{l}1.377 \\
(0.101)\end{array}$ & $\begin{array}{l}0.429 \\
(0.121)\end{array}$ \\
\hline Growth & $\Delta \ln W / L$ & $\Delta \ln S / L$ & $\Delta \ln \mathrm{VA} / L$ & $\Delta \ln K / L$ & $\Delta \ln I / L$ & $\Delta \ln S_{\text {dom }}$ & $\Delta \ln L$ & $\Delta \mathrm{PF}^{\mathrm{a}}$ \\
\hline $\begin{array}{l}\text { Exporters } \\
\qquad\left(\mathrm{EX}_{t}=1\right)\end{array}$ & $\begin{array}{l}0.007 \\
(0.063)\end{array}$ & $\begin{array}{l}0.098 \\
(0.046)\end{array}$ & $\begin{array}{l}0.176 \\
(0.051)\end{array}$ & $\begin{array}{l}0.109 \\
(0.088)\end{array}$ & $\begin{array}{l}0.075 \\
(0.166)\end{array}$ & $\begin{array}{l}0.107 \\
(0.050)\end{array}$ & $\begin{array}{l}0.042 \\
(0.026)\end{array}$ & $\begin{array}{l}0.179 \\
(0.051)\end{array}$ \\
\hline $\begin{array}{l}\text { Exporters } \\
\qquad\left(\mathrm{EX}_{t}=1\right)\end{array}$ & $\begin{array}{l}0.017 \\
(0.066)\end{array}$ & $\begin{array}{l}0.090 \\
(0.047)\end{array}$ & $\begin{array}{l}0.155 \\
(0.053)\end{array}$ & $\begin{array}{l}0.013 \\
(0.091)\end{array}$ & $\begin{array}{l}0.034 \\
(0.173)\end{array}$ & $\begin{array}{l}0.097 \\
(0.052)\end{array}$ & $\begin{array}{l}0.042 \\
(0.027)\end{array}$ & $\begin{array}{l}0.161 \\
(0.053)\end{array}$ \\
\hline $\begin{array}{l}\text { Pre-export } \\
\qquad\left(\mathrm{EX}_{t}=0 \text { and }\right. \\
\left.\qquad \mathrm{EX}_{t+i}=1\right)\end{array}$ & $\begin{array}{l}0.073 \\
(0.194)\end{array}$ & $\begin{array}{l}-0.090 \\
(0.140)\end{array}$ & $\begin{array}{l}-0.093 \\
(0.158)\end{array}$ & $\begin{array}{l}-0.093 \\
(0.270)\end{array}$ & $\begin{array}{l}0.644 \\
(0.647)\end{array}$ & $\begin{array}{l}-0.071 \\
(0.151)\end{array}$ & $\begin{array}{l}0.082 \\
(0.079)\end{array}$ & $\begin{array}{l}-0.092 \\
(0.157)\end{array}$ \\
\hline $\begin{array}{l}\text { Post-export } \\
\qquad\left(\mathrm{EX}_{t}=0 \text { and }\right. \\
\left.\mathrm{EX}_{t-i}=1\right)\end{array}$ & $\begin{array}{l}-0.163 \\
(0.103)\end{array}$ & $\begin{array}{l}-0.013 \\
(0.075)\end{array}$ & $\begin{array}{l}-0.008 \\
(0.084)\end{array}$ & $\begin{array}{l}0.108 \\
(0.144)\end{array}$ & $\begin{array}{l}0.010 \\
(0.320)\end{array}$ & $\begin{array}{l}-0.051 \\
(0.081)\end{array}$ & $\begin{array}{l}-0.080 \\
(0.042)\end{array}$ & $\begin{array}{l}0.001 \\
(0.084)\end{array}$ \\
\hline
\end{tabular}

Statistics are the coefficient estimates of an export dummy in separate firm-level regressions, controlling for country-years, industry, location and log employment (in the first five columns). The top line contains results with only current export status (and controls) as explanatory variables. The three lines below are the results for a separate regression with two extra explanatory variables: future and past export experience.

${ }^{a}$ This column contains the coefficient estimate on export status in the production function (1)-in the top paneland the first-differenced production function-in the bottom panel.

Even after controlling for size, exporters pay on average 34\% higher wages and they produce $50+\%$ more output per worker, in value added or total sales. They operate with more capital, which is sustained by a similarly increased investment rate. The largest difference is in the scale of operation. African exporters have $260 \%$ higher domestic sales and employ three times as many workers. U.S. and German exporters are only twice as large as non-exporters. The enormous size differential is less surprising in less developed countries, where the domestic market for manufactures is small.

Exploiting the time dimension of the panel, I separate future (pre-export) and previous (post-export) exporters from perennial non-exporters and distinguish the effect of the export activity from a firm fixed-effect. The size of the current sample limits what we can learn from such exercise. Of the 900 firm-years with positive exports $(23 \%$ of the sample), 128 observations are firms that just entered the export market, while 103 firms stop exporting before the end of the sample period. Results are in the next three rows of Table 3. 
The first thing to note is that all coefficients are positive and most are significantly different from zero. Regardless of their current export status, firms that are active on the export market at any point in time differ from firms that never export. This is consistent with the selection hypothesis. Secondly, all but one of the point estimates for the export dummy exceed those for pre- and post-export. Especially, the size differences increase after firms start exporting and both the size and labor productivity levels are lower once firms exit from the export market. ${ }^{5}$ Capital intensity also increases once firms start exporting and investment decreases post-export, but the differences are only significant at the $10 \%$ significance level. Observed differences between exporters and non-exporters are not fully established prior to export spells and do not outlast exit from the export market. These effects go beyond selection.

While firms might self-select into the export market based on their productivity level, this is much less likely for productivity growth. The higher labor productivity, employment, and sales growth for exporters, in the second panel of Table 3, offer corroborating evidence for an export effect. Again, the higher growth rates for exporters are not simply firm fixed-effects. Exporters are able to improve productivity, capital intensity and size, but only when they are actively exporting, not ex ante or ex post. The evidence suggests that firms hire more workers and invest heavily in years leading up to export market entry. This is not accompanied by a corresponding increase in sales and hence the labor productivity measures decline pre-export. The accumulation of inputs prior to exporting makes it likely that firms will not constantly switch in and out of the export market. Persistence in export participation is something we will have to control for.

Exporters produce more output per worker, but to some extent this is simply the result of capital deepening. To show an effect of exporting on multifactor productivity, I estimate a Cobb-Douglas production function with country-specific input coefficients ${ }^{6}$

$$
q_{i t}=\sum_{c=1}^{9}\left(\alpha_{l c} l_{i t}+\alpha_{k c} k_{i t}\right) I_{\left[i \in \operatorname{country}_{c}\right]}+\log A_{i t}+\epsilon_{i t}
$$

$$
\text { with } \log A_{i t}=\alpha_{x} \mathrm{EX}_{i t}+\omega_{c t}+\omega_{l}+\omega_{s}+v_{i t} .
$$

Exporting shifts the production frontier out if $\alpha_{x}>0$. For now I assume that productivity $\left(A_{i t}\right)$ reflects average productivity levels for the country-year, location, sector, and a firmspecific random productivity shock $v_{i t}$. The latter is assumed to be distributed i.i.d. with mean zero and independent of the measurement error $\epsilon_{i t}$. In the next section I estimate (1) under less restrictive assumptions on $v_{i t}$, and I deal with the endogeneity of $\mathrm{EX}_{i t}$.

Results in the last column of Table 3 (labeled PF) illustrate that exporters have a higher productivity level more generally. In the full sample of nine countries, exporters are on average $28 \%$ more productive. Future exporters are already $55 \%$ more productive than

\footnotetext{
${ }^{5}$ Note that only domestic sales are used to measure size.

${ }^{6}$ In every production function I estimate, the input coefficients vary by country and only the average estimates with the appropriate standard errors are reported. The more complicated estimation methods in the next section and the relatively small sample do not allow me to estimate country-industry specific coefficients. The $F$-statistic for a test of joint equality of input coefficients for all countries was three times larger than the test statistic for equality across industries.
} 
perennial non-exporters, but this advantage increases to $66 \%$ following entry (only significant at a $20 \%$ significance level). Estimating (1) in first differences with the same export dummies confirms the higher productivity growth while exporting, with negative productivity growth prior to entry. These results contrast with other studies. Using Törnqvist productivity indices, Bernard and Jensen (1999) and Aw et al. (2000) find that the productivity gap between exporters and non-exporters opens up almost entirely in the years prior to export market entry for the U.S., Taiwan, and South Korea. ${ }^{7}$

The before-after identification strategy in this section provided evidence for selfselection and hinted at productivity gains from exporting. Few differences are statistically significant in the small sample. Clerides et al. (1998) used two different identification strategies-exogeneity assumptions on lagged inputs and augmenting the production model with an export participation equation-to control explicitly for self-selection and unobserved productivity differences. In the next section, I adapt both of their methods and introduce a fourth semiparametric approach that has the added benefit of controlling for exit. In contrast with previous findings in the literature, the productivity effect of exporting does not vanish for African firms.

\section{Productivity gains from exporting}

As mentioned earlier, self-selection of more productive firms in the export market is at least partially responsible for the positive coefficient on export status in (1) - estimated at $28.4 \%$ in the last column of Table 3. A first step to control for the reverse causality from export status to productivity is to use lagged instead of contemporaneous exports. Estimating

$$
q_{i t}=\sum_{c=1}^{6}\left(\alpha_{l c} l_{i t}+\alpha_{k c} k_{i t}\right) I_{\left[i \in \operatorname{country}_{c}\right]}+\log A_{i t}+\epsilon_{i t}
$$

with $\log A_{i t}=\alpha_{x} \mathrm{EX}_{i t-1}+\omega_{c}+\omega_{l}+\omega_{s}+\omega_{i t}$.

with a random effects (RE) estimator, assuming $\omega_{i t}=\omega_{i}$ is constant over time and distributed i.i.d., reduces the productivity advantage to $26.3 \%$, results are in the first column of Table $4 .{ }^{8}$

To the extent that export market participation is correlated over time, this is only a partial fix. The dependency of input choices on productivity and sample selection generated by endogenous exit can contribute to the upward bias in the export coefficient.

\footnotetext{
${ }^{7}$ Index number measures of productivity have the advantage that no estimation is required, but for the African firms a number of underlying assumptions are likely to be violated. Factor markets are not necessarily competitive, returns to scale are increasing, and measurement error is a concern for the African data. See Van Biesebroeck (2003) for details and links to the literature. Proceeding in two steps, i.e. first calculating productivity from an econometrically estimated production function and, second, regressing productivity on export status, is inappropriate. If exporting improves productivity, it belongs in the first stage production function and to the extent that it is correlated with inputs, which was clearly shown to be the case in Table 3 , the first stage will suffer from omitted variable bias.

${ }^{8}$ For comparability with the other results in Table 4, the sample is limited to firms for which data is available in each of the 3 years. These firms come from six countries. The coefficient estimate on $\mathrm{EX}_{t}$ for this sample is $29.1 \%$.
} 
Table 4

Production function estimates, controlling for self-selection and productivity

\begin{tabular}{|c|c|c|c|c|c|}
\hline & \multirow{2}{*}{$\frac{\mathrm{RE}}{(1)}$} & \multirow{2}{*}{$\frac{\mathrm{GMM}}{(2)}$} & \multicolumn{2}{|l|}{ MLE } & \multirow{2}{*}{$\frac{\mathrm{SP}}{(5)}$} \\
\hline & & & $(3)-\left(q_{i t}\right)$ & $(4)-\left(\mathrm{EX}_{i t}\right)$ & \\
\hline \multirow[t]{2}{*}{ Labor (country average) } & 0.920 & 1.064 & 0.938 & & 0.745 \\
\hline & $(0.036)$ & $(0.10)$ & $(0.133)$ & & $(0.031)$ \\
\hline \multirow[t]{2}{*}{ Capital (country average) } & 0.223 & 0.055 & 0.086 & & 0.113 \\
\hline & $(0.019)$ & $(0.02)$ & $(0.052)$ & & $(0.020)$ \\
\hline \multirow[t]{2}{*}{$\omega_{i t-1}\left(\ln A_{i t-1}\right.$ in (4)) } & & 0.610 & 0.560 & -0.121 & \\
\hline & & $(0.06)$ & $(0.038)$ & $(0.180)$ & \\
\hline \multirow[t]{2}{*}{$\ln A_{i t-2}$} & & & & 0.517 & \\
\hline & & & & $(0.055)$ & \\
\hline \multirow[t]{2}{*}{$\mathrm{EX}_{i t-1}$} & 0.263 & 0.281 & 0.251 & 4.102 & 0.250 \\
\hline & $(0.092)$ & $(0.15)$ & $(0.121)$ & $(0.464)$ & $(0.139)$ \\
\hline \multirow[t]{2}{*}{$\mathrm{EX}_{i t-2}$} & & & & 1.523 & \\
\hline & & & & $(0.474)$ & \\
\hline Observations & 1410 & 705 & 705 & 705 & 705 \\
\hline \multicolumn{6}{|c|}{ For all tests the $p$-values are reported: } \\
\hline \multirow{2}{*}{\multicolumn{2}{|c|}{$\begin{array}{l}\mathrm{H}_{0}: \mathrm{EX}_{t-i}=0, \forall i \\
\mathrm{H}_{0}: \mathrm{EX}_{t-i} \\
\text { exogenous }\end{array}$}} & 0.07 & 0.04 & 0.00 & 0.07 \\
\hline & & 0.04 & & & \\
\hline \multicolumn{2}{|l|}{ Sargan test } & 0.11 & & & \\
\hline
\end{tabular}

The estimation methods are described (1) at start of Section 3; (2) in Section 4.1; (3) and (4) in Section 4.2; and (5) in Section 4.3.

Under fairly general assumptions, Olley and Pakes (1996) show that the labor coefficient will be upward and the capital coefficient downward biased. This will overestimate the productivity level of more capital-intensive firms, such as exporters. The three sources of endogeneity are now addressed explicitly.

\subsection{Instrumental variables (GMM-SYS)}

If one observes variables that predict export status, but are uncorrelated with the unobserved productivity, instrumental variable estimation is a flexible solution. Two instruments are used: the ethnicity of the owner and (some) state ownership. Ethnicity of the owner influences the extent of foreign contacts. The intuition is that an owner that belongs to a domestic minority or speaks a foreign language makes the firm more likely to export. Firms with some state ownership are, ceteris paribus, less likely to export. Including either of these variables in the production function gave insignificant results (the $p$-value of joint significance is 0.38 ). The instrument set, including the lagged inputs that instrument for current inputs, passes the Sargan test for overidentifying restrictions ( $p$-value is 0.11$){ }^{9}$

\footnotetext{
${ }^{9}$ When the coefficient restrictions on the lagged inputs and output are not enforced, results in Van Biesebroeck (2003), the $p$-value of the Sargan test even rises to 0.28. The lagged input variables, not the instruments for export status, seem to be the weakest instruments.
} 
To account for the simultaneity of input choices and unobserved productivity, I use the GMM-SYS estimator of Blundell and Bond (1998). I also adopt a less restrictive specification for $\omega_{i t}$. Specifically, I assume that $\omega_{i t}=\rho \omega_{i t-1}+v_{i t}$. Quasi-differencing Eq. (2) to eliminate serial correlation due to $\omega_{i t}$ yields the output equation I estimate:

$$
\begin{aligned}
q_{i t}= & \alpha_{l c}\left(l_{i t}-\rho l_{i t-1}\right)+\alpha_{k c}\left(k_{i t}-\rho k_{i t-1}\right)+\alpha_{x}\left(\mathrm{EX}_{i t-1}-\rho \mathrm{EX}_{i t-2}\right)+\rho q_{i t-1} \\
& +(1-\rho)\left(\omega_{c}+\omega_{l}+\omega_{s}\right)+\epsilon_{i t}+v_{i t} .
\end{aligned}
$$

To interpret the coefficients in Table 4, note that Eq. (4) can be written as $\left(\varepsilon_{i t} \equiv \epsilon_{i t}+v_{i t}\right)$

$$
q_{i t}=\alpha_{l c} l_{i t}+\alpha_{k c} k_{i t}+\alpha_{x} \mathrm{EX}_{i t-1}+\rho \omega_{i t-1}+\omega_{c}+\omega_{l}+\omega_{s}+\varepsilon_{i t} .
$$

Following Blundell and Bond (1998), twice lagged inputs and output are instruments in the differenced equation and lagged first differences of inputs are instruments in the level equation. Both versions are estimated jointly as a system. This way one controls for the persistent part of unobserved productivity without throwing away the information contained in the levels.

The results are in the second column of Table 4. Exogeneity of the export status can be tested with a Durbin-Hausman specification test. The $p$-value for the test-statistic is 0.04 and I reject the exogeneity assumption. The GMM method is fairly flexible, but the use of twice lagged instruments reduces the sample to six countries and we find only marginally significant, but positive, effects of lagged export status.

\subsection{Modeling export participation (MLE)}

An alternative is to model the exporting decision explicitly and jointly estimate it with the production function. This approach is more demanding in terms of economic assumptions (and programming effort), but generates more precise estimates. Clerides et al. (1998) pioneered this approach to jointly estimate a variable cost equation with a selection rule for entry into the export market, drawing on the model by Roberts and Tybout (1997). Normally distributed productivity effects are allowed to be correlated across equations. For Colombia and Morocco, they find that lagged export status is insignificant in the cost function, while lagged costs do predict export status. They conclude in favor of the self-selection hypothesis and against learning-byexporting. ${ }^{10}$

I assume that productivity evolves according to

$$
\log A_{i t}=\alpha_{x} \mathrm{EX}_{i t-1}+\omega_{1 i}+\omega_{i t} .
$$

$\omega_{i t}$ follows an $\mathrm{AR}(1)$ process as before and $\omega_{1 i}$ is a firm-specific random effect that replaces the country, industry, and location dummies. Quasi-differencing the production

\footnotetext{
${ }^{10}$ Kraay (1999) and Bigsten et al. (2004) estimate a similar model for China and four African countries and find some evidence of learning. The latter uses some of the same data as this paper, but limits the sample to only 289 firms in four countries and forces the same input coefficients on all countries. They find a significant effect of exporting only when the unobserved productivity terms are assumed to follow a discrete distribution with three points of support, not if they are normally distributed.
} 
function as in Eq. (4) and collecting all lagged terms in $\omega_{i t-1}$, the system of equations I estimate is given by

$$
\begin{aligned}
& q_{i t}=\alpha_{l c} l_{i t}+\alpha_{k c} k_{i t}+\alpha_{x} \mathrm{EX}_{i t-1}+\rho \omega_{i t-1}+\omega_{1 i}+\varepsilon_{1 i t} \\
& \mathrm{EX}_{i t}= \begin{cases}1 & \text { if } \sum_{\tau=1}^{2}\left(\beta_{a \tau} \ln A_{i t-\tau}+\beta_{x \tau} \mathrm{EX}_{i t-\tau}\right)+\gamma_{z 1} Z_{i t}^{1}+\gamma_{z 2} Z_{i t}^{2}+\omega_{2 i}+\epsilon_{2 i t} \geq 0 \\
0 & \text { otherwise. }\end{cases}
\end{aligned}
$$

In the estimation $\omega_{i t-1}$ is replaced by $\left(q_{i t-1}-\alpha_{l c} l_{i t-1}-\alpha_{k c} k_{i t-1}-\alpha_{x} \mathrm{EX}_{i t-2}-\omega_{1 i}\right)$ and $\varepsilon_{1 i t} \equiv \epsilon_{i t}+v_{i t}$, as in the previous section. The decision to export is a function of once and twice lagged export experience and productivity, to respectively capture sunk costs of exporting and self-selection into the export market. Rearranging (2), $\ln A_{i t-\tau}$ is replaced by $\left(q_{i t-\tau}-\alpha_{l c} l_{i t-\tau}-\alpha_{k c} k_{i t-\tau}\right)$ and captures the full firm-level productivity, including the effect of previous export experience. The explanatory variables $Z^{1}$ and $Z^{2}$ are the same exogenous determinants of export status used as instruments in the previous section.

The remaining estimation issues are handled as in Clerides et al. (1998). Both error terms $\varepsilon_{1}$ and $\epsilon_{2}$ are assumed to be i.i.d. normally distributed. The unobserved productivity terms $\omega_{1}$ and $\omega_{2}$ are integrated out using Gaussian quadrature, allowing for correlation between both terms. Lagged equations containing only the exogenous variables and nuisance parameters are added to the system to solve the initial values problem. For the full likelihood function, see Clerides et al. (1996). Results for the production function are in the third column and for the export participation in the fourth column of Table 4.

\subsection{Semiparametric estimation (SP)}

As a third robustness check, I adapt the semiparametric estimator from Olley and Pakes (1996). This approach controls additionally for endogenous exit from the sample that is assumed to happen when productivity falls below a threshold. In particular, Olley and Pakes (1996) argue that plants with more capital, such as exporters, are likely to weather greater reductions in productivity, making the exit threshold a decreasing function of capital. $^{11}$

Pakes (1994) proves that the investment function, $I_{t}=i_{t}\left(K_{t}, \omega_{t}\right)$, a function of the two state variables, capital and productivity, is monotonically increasing in productivity. This generalizes readily to the Olley and Pakes (1996) situation where there is an additional (observed) state variable, age, that evolves deterministically. Inverting the investment relationship produces an expression for the unobserved state variable, productivity, as an unknown function of investment, capital, and age. Variable input coefficients can be recovered using nonparametric techniques from a first estimation step, where the expression for productivity is substituted in the production function. In a second step, the survival probability of a plant is predicted from a nonparametric probit regression. In a third and final step, coefficients on the state variables-capital and age-are recovered, using semiparametric nonlinear least squares.

\footnotetext{
${ }^{11}$ For example, due to imperfections in the capital market or a profit function that is increasing in capital.
} 
The difference in our application is that the second state variable, lagged export status instead of age, does not evolve deterministically. The current export status is chosen simultaneously with current investment. Formally, $K_{t}, \mathrm{EX}_{t-1}$, and $\omega_{t}$ are the state variable at the start of period $t$. The firm has two controls $I_{t}$ and $\Delta \mathrm{EX}_{t}=\mathrm{EX}_{t}-\mathrm{EX}_{t-1}$, which determine the evolution of the state variables: $K_{t+1}=(1-\delta) K_{t}+I_{t}$, $\mathrm{EX}_{t}=$ $\mathrm{EX}_{t-1}+\Delta \mathrm{EX}_{t} \cdot \omega_{t+1}$ is assumed to follow a stochastic Markov process, only as a function of $\omega_{t}{ }^{12}$

The policy function for investment is an unknown function of the three state variables, $I_{t}=i_{t}\left(K_{t}, \mathrm{EX}_{t-1}, \omega_{t}\right)$. Similarly, there exists a policy function for the (change in) export status, $\Delta \mathrm{EX}_{t}=\Delta \operatorname{ex}_{t}\left(K_{t}, \mathrm{EX}_{t-1}, \omega_{t}\right)$, which will not be used in this estimator. ${ }^{13}$ The firm decides whether to export next period knowing the previous period's export status, the current capital stock, and the current productivity level, including the part unobserved to the econometrician, $\omega_{t}$. The current export decision only affects the firm's productivity level the following period, according to Eq. (3), just as today's investment only raises tomorrow's capital stock.

I conjecture that under appropriate assumptions $i_{t}(\cdot)$ will still be a monotonic function in $\omega_{t}$ and can be inverted to provide an expression for productivity as an unknown function of observables. ${ }^{14}$ Exporters will make different investment decisions, even controlling for capital and productivity, because of different market prospects. In the estimation step, the nonparametric inversion is made export status specific.

In the second estimation step, the probability a firm exits from the sample is captured by the probability the end-of-period productivity falls below the exit-threshold: Prob(exit after period $t)=\operatorname{Prob}\left(\omega_{t+1} \leq \omega_{t+1}\left(K_{t+1}, \mathrm{EX}_{t}\right) \mid \omega_{t+1}, \underline{\omega}_{t}\right)$. This can be written as an unknown function of current observables by substituting the transition equations for the state variables and the previously used expression for productivity: $\operatorname{Prob}(\mathrm{exit})=P_{t}\left(K_{t+1}, \mathrm{EX}_{t}\right.$, $\left.\omega_{t}\right)=P_{t}^{\prime}\left(K_{t}, I_{t}, \mathrm{EX}_{t-1}, \Delta \mathrm{EX}_{t}\right)$ or equivalently $P_{t}^{\prime \prime}\left(K_{t}, I_{t}, \mathrm{EX}_{t-1}, \mathrm{EX}_{t}\right)$. Both the lagged and current export status figure in the equation, but for different reasons. Lagged export status is needed because next period's productivity depends on current productivity and lagged

\footnotetext{
${ }^{12}$ I follow Olley and Pakes (1996) in assuming that the policy variables have no impact on the evolution of $\omega_{t}$. The productivity effect of exporting is modeled directly into the production function (3) and does not work through the unobserved component of productivity.

${ }^{13}$ A variant of the exporting control was used in the MLE estimation.

14 Appendix I in Pakes (1994) proves monotonicity of the investment equation if the period payoff function, $\pi(\omega, k)-c(i, k)$, satisfies two conditions: $\partial \pi(\omega, k) / \partial k$ is increasing in $\omega$ and $\partial c\left(i, k_{1}\right) / \partial_{i} \leq \partial c\left(i, k_{2}\right) / \partial_{i}$ whenever $k_{1} \geq k_{2}$. In the current context, we use an expanded payoff function, $\pi(\omega, k$, ex $)-c_{1}(i, k)-c_{2}(\Delta \mathrm{ex}$, ex $)$, and add equivalent assumptions on the dependency of the payoff function on the (discrete) lagged exporting state (ex) and the exporting control $(\Delta \mathrm{ex}): \pi(\omega, k, \mathrm{ex}=1)-\pi(\omega, k, \mathrm{ex}=0)$ is increasing in $\omega(\forall k),\left[c_{2}(\Delta \mathrm{ex}=0\right.$, $\left.\mathrm{ex}=1)-c_{2}(\Delta \mathrm{ex}=-1, \mathrm{ex}=1)\right] \leq\left[c_{2}(\Delta \mathrm{ex}=1, \mathrm{ex}=0)-c_{2}(\Delta \mathrm{ex}=0, \mathrm{ex}=0)\right]$, and $c_{2}(\Delta e x=0$, ex $=1) \leq c_{2}(\Delta e x=0$, $e x=0)$. The first condition states that the marginal return to exporting is increasing in productivity, which will be satisfied for price taking firms operating with our production function. The second condition assumes that the cost-savings for an exporter that quits the export market are smaller than the cost a non-exporter has to incur to enter the export market, which will be satisfied if there are sunk costs to exporting, as in Roberts and Tybout (1997). The third condition will be satisfied if no costs are incurred when the export status does not change, similarly as for investment. Finally, we conjecture that additionally assuming that $\partial \pi(\omega, k, \mathrm{ex}=1) / \partial k \geq \partial \pi(\omega, k$, $\mathrm{ex}=0) / \partial k$, which is satisfied by our production function, will guarantee that both policy functions, for investment and exporting, are monotonically increasing in $\omega$. A sketch of the proof is available upon request.
} 
export status belongs in the equation that predicts the unobservable $\omega_{t} \cdot{ }^{15}$ Current export status belongs in the exit-threshold, because it moves the production function, hence also the profit function, for next period. The production function coefficients of both state variables, capital and lagged export status, are recovered in the third estimation step, following Olley and Pakes (1996) p. 1276. Results are in the fifth column of Table 4.

\subsection{Results}

The first column in Table 4 shows the random effects (RE) results as benchmark. Country-year, industry, and location dummies are included in each equation, but not reported. Input coefficients vary by country, but only the average estimates and appropriate standard errors are reported.

The coefficient on lagged export status is estimated positive and very similar in magnitude in all specifications. Engaging in exporting shifts the production function out by $25 \%$ to $28 \%{ }^{16}$ Tests for the null hypothesis of no effect of exporting on productivity after controlling for self-selection, are rejected at the 10\% significance level for the GMM and SP results and at the 5\% level for the MLE results.

Comparing the first two columns in Table 4 gives the counterintuitive result that instrumenting for export status raises the coefficient estimate of the export effect. One reason is the slightly lower estimate for scale economies, 1.119 versus 1.143 , given that exporters are substantially larger on average. A second reason, heterogeneity in export effects, is often apparent in the literature on treatment effects if instrumental variables are used for identification. ${ }^{17}$ If the effect of exporting on productivity varies across firms, the point estimate of the export dummy will depend on the observations that drive identification. Some firms enter the export market because of high initial productivity, without deriving much benefit from that activity. However, the productivity effect of exporting is identified from firms that enter the export market for different reasons. They export, for example, because the owner has family or business partners abroad, even though their productivity level by itself does not warrant entry into the export market. These firms have more scope for productivity improvements facing the same foreign exposure, making the higher coefficient estimate not implausible.

The third and fourth columns in Table 4 contain the results of joint estimation of the production function and export participation with maximum likelihood. Most coefficients are now significantly different from zero at the 5\% significance level. The results lend support to the self-selection and learning-by-exporting hypothesis. The positive and large coefficient on twice lagged productivity $\left(\ln A_{i t-2}\right)$ in the export participation equation, confirms that highly productive firms are more likely to enter the export market. The large coefficients on once and twice lagged export status in the same

\footnotetext{
15 The estimated exit probability for current exporters will vary by $\mathrm{EX}_{t-1}$, because lagged export status determines what signal about $\omega_{t}$ we can extract from current investment levels, conditional on capital.

${ }^{16}$ Bigsten et al. (2004) find a very similar point estimate of 0.23 on lagged export status in a value added production function using their preferred estimator. Similar results for a longer sample of five years for Ghana are reported in Van Biesebroeck (2003).

${ }^{17}$ See Card (2001) for an example in a similar econometric context.
} 
equation indicates sunk costs of entry; past export activity is one of the best predictors for current export activity. ${ }^{18}$

The positive coefficient on lagged exports in the third column indicates that previous export activity raises current output on average by $25 \%$, even controlling for the selection effect. The effect is slightly smaller than the random effects benchmark. If this effect still seems (implausibly) large, one should keep in mind that the productivity dispersion in Africa substantially exceeds dispersion in the U.S. ${ }^{19}$ The lower estimate for scale economies would lead, ceteris paribus, to a higher exporting effect. Controlling for selfselection yields a net effect slightly below the random effect benchmark.

The results for the semiparametric estimator, in the fifth column, confirm the findings. As expected, the labor coefficient is estimated lower than with the random effects estimator. Relative to the random effects results, the export coefficient is estimated slightly lower, at $25 \%$, but less precisely. Controlling for exit from the sample has little impact on the results. Recall that the sample is not a census and there are many causes for firms to disappear.

All four identification strategies that failed to find productivity effects of exporting in other countries point towards firms benefiting from previous export activity in Africa. A natural next step is to question what form these benefits take.

\section{Sources of productivity advantage}

\subsection{Returns to scale}

The most straightforward benefit for exporters is access to a larger market. The domestic market in each sample country is small and returns to scale are estimated to be increasing. In a survey of manufacturing in developing countries, Tybout (2000) mentions that scale economies are smaller than commonly expected. He cites, based on studies for Asia, Latin America and Northern Africa, returns to scale between 1.05 and 1.10; comparable to most of the estimates I find for Africa in Table 4, only the semi-parametric estimator came up with lower scale economies. Such mild economies of scale are unlikely to be the cause of the stalled development process, but profit maximizing firms will try to exploit them, for example by exporting.

Because exporters are larger to start with and increase in size with entry into the export market, estimated productivity advantages depend crucially on the returns to scale assumption. Enforcing constant returns to scale (CRS) raises the productivity effect attributed to exporting substantially as the export dummy absorbs some of the size effect. The first two columns in Table 5 show an export advantage of $45 \%$ under CRS relative to $22 \%$ under VRS. Half of the export effect is realized by exploiting scale economies if these are assumed identical for all firms.

\footnotetext{
${ }^{18}$ If only a single lag of productivity is included, the coefficient on $\ln A_{i t-1}$ is estimated significantly positive at 0.452 (S.E. 0.078).

${ }^{19}$ Van Biesebroeck (2005) shows that the productivity ratio for the 80th to the 20th percentile firm in the different African countries ranges from 4.1 in Zimbabwe to $\geq 9$ in Ethiopia, Ghana, and Zambia. The comparable ratio for U.S. manufacturing plants was 2.75 in 1987.
} 
Table 5

Testing for differences in technology and scale economies

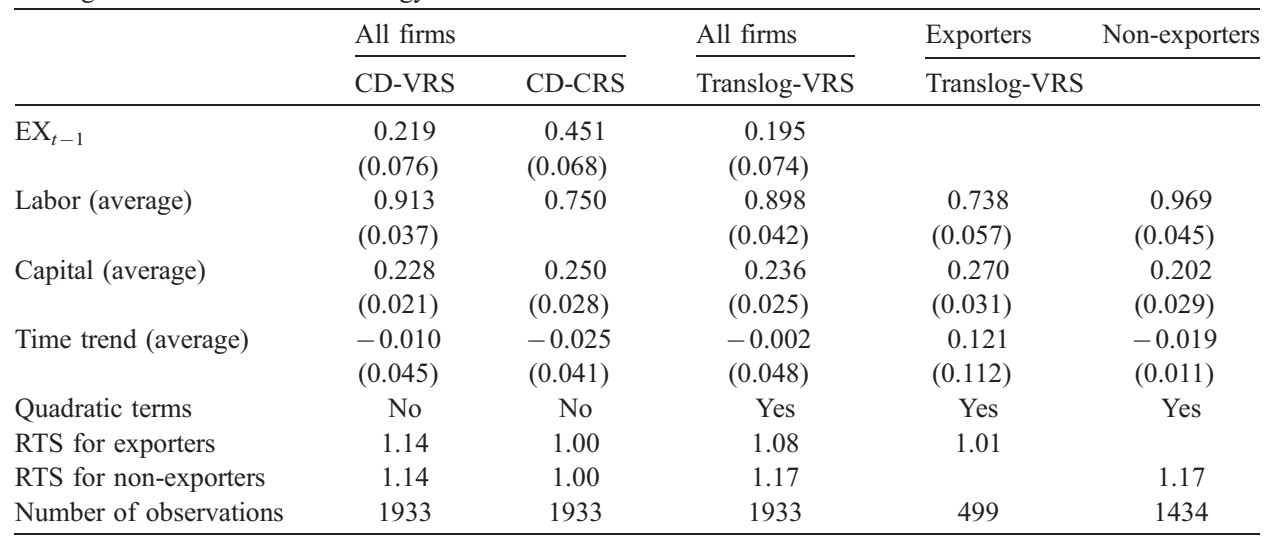

Estimation is with random effects as column (1) in Table 4, controlling for country-year, industry, and location. Linear and quadratic (not reported) coefficients on inputs and time vary by country.

A more flexible specification of the production technology should allow scale economies to vary by firm size. Estimation results for a translog production function are in the third column of Table 5. Country-specific quadratic and interaction terms are included, but not reported. ${ }^{20}$ Average scale economies are still estimated to be increasing, at 1.13 , but evaluating the function separately for the average exporter and nonexporter shows a clear difference. Returns to scale are estimated higher for non-exporters, 1.17 versus 1.08 , and the difference is statistically different at a 1\% significance level. Exporters exhaust most of the scale economies that the common production frontier allows.

One could even argue that the two groups of firms do not operate with the same technology. Exporters are different in many respects. They have a higher capital-labor ratio, invest more frequently, have higher value added as a percentage of sales, introduce new technologies more frequently, and are more likely to have a formal training program for employees. Adoption of advanced production technologies could provide another channel for exporters in developing countries to improve productivity. ${ }^{21}$

The last two columns of Table 5 show results for production functions estimated separately for exporters and non-exporters. Exporters do not only differ in productivity level and returns to scale, but also in input elasticities and average productivity growth. Returns to scale are not significantly different from unity for exporters, indicating that these firms have exhausted scale economies, while non-exporters still face significant increasing returns to scale. The exporters' technology is also more capital intensive-the capital coefficient is $27 \%$ of the sum of both inputs versus $17 \%$ for non-exporters. The higher capital-labor ratio in Table 3 is not only driven by factor price differences. Finally, productivity growth is higher for exporters, $+12 \%$ versus $-2 \%$.

\footnotetext{
${ }^{20}$ Inputs are normalized to have mean zero by country, which gives the linear coefficients the same interpretation as in a Cobb-Douglas production function.

${ }^{21}$ Van Biesebroeck (2005) provides evidence using the same data. Barro and Sala-i-Martin (1997) build a model where countries copy technologies from more advanced trading partners, leading to income convergence.
} 
Table 6

Contracts and credit

\begin{tabular}{|c|c|c|c|c|}
\hline & \multicolumn{2}{|c|}{ Exporters } & \multicolumn{2}{|c|}{ Non-exporters } \\
\hline & Small $^{\mathrm{a}}$ & Large & Small & Large \\
\hline One of main problems is lack of credit & 0.51 & 0.39 & 0.58 & 0.41 \\
\hline One of main problems is lack of demand & 0.19 & 0.26 & 0.30 & 0.28 \\
\hline One of main problems is infrastructure & 0.14 & 0.15 & 0.15 & 0.16 \\
\hline (Number of observations) & $(204)$ & $(696)$ & $(2394)$ & $(557)$ \\
\hline Trade credit received (as \% of sales) & 0.103 & 0.181 & 0.080 & 0.085 \\
\hline Trade credit given (as \% of sales) & 0.677 & 0.180 & 0.144 & 0.108 \\
\hline Formal loans received (as \% of sales) & 0.126 & 0.203 & 0.143 & 0.218 \\
\hline (Number of observations) & $(366)$ & $(534)$ & $(2676)$ & $(275)$ \\
\hline Late or non-payment by a client ${ }^{\mathrm{b}}$ & 0.66 & 0.66 & 0.59 & 0.66 \\
\hline Number of non-payments (if any) ${ }^{b}$ & 5 & 12 & 4 & 6 \\
\hline Last problem was with a foreign client & 0.08 & 0.09 & & \\
\hline (Number of observations) & $(135)$ & $(210)$ & $(1147)$ & $(134)$ \\
\hline
\end{tabular}

${ }^{\text {a }}$ The small-large firm sample split is at 100 employees.

${ }^{\mathrm{b}}$ In last year, excluding foreign clients.

The Chow test for a structural break in the sample, which assumes equal variance of the residual for both types, rejects that exporters and non-exporters share the same technology. The $\chi^{2}$-distributed test statistic is 2.86 , while the critical value for a $1 \%$ significance level is 1.94. The Wald test, which allows for different variances, confirms this result. The $F$ statistic is 22.08 , while the $1 \%$ critical value is $13.28 .^{22}$

\subsection{Trade credit and contract defaults}

When asked directly, $16 \%$ of the owners or managers mention that insufficient demand is the principal limit to expansion. Almost a third lists it among the top three problems (Table 6). This suggests that many firms operate at a smaller scale than they would like. It is a particularly acute problem for small non-exporters, while small exporters mention it the least (30\% versus $19 \%$ ). Using 50 instead of 100 workers as cutoff level for small firms raises the problem count to $34 \%$ versus $10 \%$ for similarly sized exporters. The largest problem for these firms is the limited availability of formal credit. Domestically oriented firms are again more likely to report being constrained. ${ }^{23}$

I want to argue that both problems are related. In order to increase sales, firms often extend trade credit to their (credit constrained) clients. The outstanding amounts of different types of credit as a percentage of total sales are listed in Table 6. Exporters, especially smaller ones, award substantially more trade credit. For formal credit, the big difference is between large and small firms, while export status hardly matters. ${ }^{24}$

\footnotetext{
${ }^{22}$ Interestingly, splitting the sample between large and small firms only matters for the scale economy estimate. The differences in capital intensity and productivity growth are not simply related to size.

${ }^{23}$ In contrast, the third most important problem, inappropriate infrastructure, is equally important for firms of different size and independent of export orientation.

${ }^{24}$ Table B.3 in Van Biesebroeck (2003) contains more detailed information on the importance of trade credit, as well as the average credit term.
} 
The difficulty enforcing contracts in Africa makes expanding sales through trade credit particularly risky. Payments are often late, leading to disputes and renegotiations, see Bigsten et al. (2000). Almost two thirds of the firms report having late or nonpayment problems with domestic clients in the last year and they generally report multiple incidences, between 4 and 12 a year, on average. Sales to foreign firms, on the other hand, are significantly less likely to lead to disputes. Exporters report that only $8 \%$ of all clientrelated payment problems are with foreign firms, even though they account for more than $30 \%$ of sales. ${ }^{25}$ When a problem with a foreign firm arises it is three out of four times the first business contact. In contrast, in five out of six incidents of payment problems with domestic firms, the two sides already had an established business relationship. It is not surprising then that exporters extend trade credit more easily to their clients, aiding expansion and the realization of scale economies. In addition, specific institutions, such as an order bill of lading exist to facilitate this practice. Once the goods are shipped off to the client, the seller's bank arranges payment directly with the client's bank, taking over the seller's contract risk.

To evaluate the empirical relevance of the previous argument and to verify the impact on the estimated self-selection and export effects, I reestimate the model from Section 4.2, with three extra determinants of the export decision. I find that firms are slightly more likely to start exporting if previously they experienced contractual problems with clients, reported to be demand constrained, or extended a lot of trade credit. All effects are estimated imprecisely; results are in Van Biesebroeck (2003). The selection into the export market based on these "problem" variables shows up, but is very weak. Lagged export status and productivity differences remain the most important determinants of exporting.

Even if firms self-select into the export market to reduce domestic contractual problems, they can still reap additional benefits from their export activities down the road, e.g. realizing scale economies or adopting a technology with higher productivity growth. The exogenous characteristics used to identify firms that export for other than productivity reasons are correlated with the incidence of contractual problems, lack of demand, and excessive trade credit in earlier periods. Some of the productivity effects of exporting identified in Section 4 may fundamentally stem from foreign sales solving domestic problems, rather than shifting out the (technological) production frontier.

\section{Conclusions}

Exporters in sub-Saharan Africa, like exporters elsewhere, are more productive than domestically oriented firms in the same location and industry. But unlike exporters in other regions, African exporters improve their relative performance after they enter foreign markets. They not only have higher post-entry productivity levels, but also higher postentry rates of productivity growth. This productivity advantage for exporters remains after controlling for the endogenous export decision with instrumental variables, when the export participation is estimated jointly with the production function, or when sample selection is controlled for nonparametrically.

\footnotetext{
${ }^{25}$ Payment by foreign clients turns out to be as reliable as payment by family members.
} 
Returns to scale are particularly important to explain the productivity gap. Exporters have exhausted scale economies, while non-exporters are producing at a point on the production frontier with significant increasing returns to scale. One can even reject the hypothesis that both types of firms produce with the same technology; consistent with theoretical models that assume exporters acquire more advanced technologies first. Exporting also solves the "lack of demand" problem that many firms report, as the scope for domestic expansion is limited by the lack of formal credit. Higher risk associated with trade credit makes extending credit to domestic clients an especially risky expansion strategy. Exporting provides access to a more reliable client base and to institutions that specifically deal with credit risks associated with foreign trade. This effect has not been documented before and warrants further investigation.

\section{Acknowledgements}

I would like to thank Marcel Fafchamps for his help to get me access to the data. Thanks also go to Frank Wolak, Lanier Benkard, Peter Reiss, Bruce Blonigen and participants at the 2002 NBER URC-ITI conference for comments on a previous version. The editor, Jim Tybout, and an anonymous referee provided extensive comments and suggestions that improved the paper greatly. Financial support from the Littlefield Fellowship, SSHRC, and the K.U. Leuven is gratefully acknowledged.

\section{References}

Aw, B.Y., Hwang, A., 1995. Productivity and the export market: a firm-level analysis. Journal of Development Economics 47 (2), 313-332.

Aw, B.Y., Chung, S., Roberts, M.J., 2000. Productivity and turnover in the export market: micro-level evidence from the Republic of Korea and Taiwan (China). World Bank Economic Review 14 (1), 65 -90 (January).

Barro, R.J., Sala-i-Martin, X., 1997. Technological diffusion, convergence, and growth. Journal of Economic Growth 2 (1), 1-26 (March).

Bernard, A.B., Jensen, J.B., 1995. Exporters, jobs, and wages in U.S. manufacturing, 1976-1987. Brookings Papers on Economic Activity. Brookings, Washington DC, pp. 67-119.

Bernard, A.B., Jensen, J.B., 1999. Exceptional exporter performance: cause, effect, or both? Journal of International Economics 47 (1), 1-26.

Bernard, A.B., Wagner, J., 1997. Exports and success in German manufacturing. Weltwirtschaftliches Archiv 133 (1), $134-157$.

Bigsten, A., Collier, P., Dercon, S., Fafchamps, M., Gauthier, B., Gunning, J.W., Isaksson, A., Oduro, A., Oostendorp, R., Pattillo, C., Teal, F., Zeufack, A., 2000. Contract flexibility and dispute resolution in African manufacturing. Journal of Development Studies 36 (4), 1-17 (April)

Bigsten, A., Collier, P., Dercon, S., Fafchamps, M., Gauthier, B., Gunning, J.W., Oduro, A., Oostendorp, R., Pattillo, C., Söderbom, M., Teal, F., Zeufack, A., 2004. Do African manufacturing firms learn from exporting. Journal of Development Studies 40 (3), 115-141 (February).

Blundell, R.W., Bond, S.R., 1998. Initial conditions and moment restrictions in dynamic panel data models. Journal of Econometrics 87, 115-143.

Card, D., 2001. Estimating the return to schooling: progress on some persistent econometric problems. Econometrica 69 (5), 1127-1160 (September).

Clerides, S., Lach, S., Tybout, J., 1996. Is learning by exporting important? Micro-dynamic evidence from Colombia, Mexico, and Morocco. NBER Working Paper, 5715. 
Clerides, S.K., Lach, S., Tybout, J.R., 1998. Is learning by exporting important? Micro-dynamic evidence from Colombia, Mexico, and Morocco. Quarterly Journal of Economics 113 (3), 903-947.

Delgado, M.A., Farinas, J.C., Ruano, S., 2002. Firm productivity and export markets: a non-parametric approach. Journal of International Economics 57, 397-422.

Heckman, J.J., Singer, B., 1984. A method for minimizing the impact of distributional assumptions in econometric models for duration data. Econometrica 52, 271-320.

Isgut, A.E., 2001. What's different about exporters? Evidence from Colombian manufacturing. Journal of Development Studies 37 (5), 57-82 (June).

Kraay, A., 1999. Exportations et Performances Economiques: Etude d'un Panel d'Entreprises Chinoises. Revue d'Economie Du Developpement 0 (1-2), 183-207.

Mengistae, T., Patillo, C., 2004. Export orientation and productivity in sub-Saharan Africa. IMF Staff Papers 51 (2), 327-353.

Olley, G.S., Pakes, A., 1996. The dynamics of productivity in the telecommunications equipment industry. Econometrica 64 (6), 1263-1297.

Pakes, A., 1994. Dynamic structural models, problems and prospects: mixed continuous discrete controls and market interactions. In: Laffont, J.-J., Sims, C. (Eds.), Advances in Econometrics: The Sixth World Congress of the Econometric Society, volume II, Chapter 5. Cambridge University Press, New York, pp. 171-260.

Roberts, M., Tybout, J., 1997. The decision to export in Colombia: an empirical model of entry with sunk costs. American Economic Review 87, 545-564 (September).

Tybout, J.R., 2000. Manufacturing firms in developing countries: how well do they do, and why? Journal of Economic Literature 28, 11-44 (March).

Tybout, J.R., Westbrook, M.D., 1995. Trade liberalization and the dimensions of efficiency change in Mexican manufacturing industries. Journal of International Economics 39, 53-78.

Van Biesebroeck, J., 2003. Exporting raises productivity in sub-Saharan African manufacturing firms. NBER Working Paper 10020 (October).

Van Biesebroeck, J., 2005. Firm size matters: growth and productivity growth in African manufacturing. Economic Development and Cultural Change 53 (3), 545-583 (April).

World Bank (2000). African development indicators. Washington D.C.: the World Bank. Computer file. 